\title{
Comparative study of maternal and perinatal outcome in pregnancies with and without umbilical cord around foetal neck
}

\author{
Pundalik K. Sonawane*, Deep M. Bhadra
}

Department of Obstetrics and Gynecology, K. J. Somaiya Medical College, Mumbai, Maharashtra, India

Received: 09 January 2019

Accepted: 05 February 2019

\section{*Correspondence:}

Dr. Pundalik K. Sonawane,

E-mail: drpundalik@gmail.com

Copyright: (C) the author(s), publisher and licensee Medip Academy. This is an open-access article distributed under the terms of the Creative Commons Attribution Non-Commercial License, which permits unrestricted non-commercial use, distribution, and reproduction in any medium, provided the original work is properly cited.

\begin{abstract}
Background: Umbilical cord around neck of the foetus is called the nuchal cord. The aims and objectives are to find out the incidence of nuchal cord around foetal neck at delivery, and to compare and evaluate intrapartum and postpartum maternal and foetal outcome in those with or without nuchal cord at delivery.

Methods: It is a prospective cross-sectional study conducted at tertiary care hospital for period of 12 months. Of 1380 patients, 934 patients were enrolled in present study after meeting the inclusion and exclusion criteria of which 150 patients were included in study group who delivered with nuchal cord and 784 patients in control group who delivered without nuchal cord.

Results: Present study showed $18.84 \%$ incidence of nuchal cord at delivery. Duration of labour was $6.51 \mathrm{hrs}$ in study group and $6.15 \mathrm{hrs}$ in control group and the difference was statistically significant. Rest of the intrapartum and postpartum events were statistically not significant. Mean length of cord was more in patients delivered with loop of cord around foetal neck as compared to another group and it is statistically significant.

Conclusions: Nuchal cord is a common finding at the time of delivery. However, it is per-se not an indication of LSCS and it only increases the operative morbidity.
\end{abstract}

Keywords: LSCS, Labour, Nuchal cord

\section{INTRODUCTION}

Presence of umbilical cord around any fetal part, especially around fetal neck is frequently encountered in obstetric practice which causes considerable anxiety to women and treating obstetrician. Presence of nuchal cord may affect fetus's status during labour, at birth and after birth. ${ }^{1}$ Nuchal cords are seen in $13-30 \%$ of births with its prevalence increases with duration of pregnancy, from $5.8 \%$ at 20 wks upto $29 \%$ at 42 weeks of gestation. The incidence of nuchal cord rose with advancing gestation from $12 \%$ at 24 to 26 weeks to $37 \%$ at term. However, at each gestational age, its occurrence was a random or chance event and was not associated with clinical evidence of fetal compromise before labor. Antenatal nuchal cords usually occur randomly with increased frequency in late gestation and appear to be a normal part of intrauterine life that is rarely associated with perinatal morbidity and mortality which was similar to study conducted by Miser WF. ${ }^{2,3}$ The results of the study conducted by Jauniaux E. suggest that sonographic identification of nuchal cord may be an important observation during third trimester sonography, particularly when evaluating cases of decreased fetal movements. ${ }^{4}$ Ultrasonographers can look for a "divot" sign on high-resolution ultrasound, a circular indentation of the fetal nuchal skin; but care should be exercised not to confuse this finding with posterior cystic masses, folds of skin, or amniotic fluid pockets. ${ }^{5}$ Krakowiak, et al noted that short cords $(<40 \mathrm{~cm})$ are more likely to wrap tightly 
around neck and are assosciated with higher incidence of decreased fetal movements, cord compression and cord constriction and cord rupture. ${ }^{6}$ It was also assosciated with low APGAR scores, low IQ values, neurologic abnormalities and still births. Naeye, et al showed that long cords (defined as $>70 \mathrm{~cm}$ length) have poor fetal outcome, higher fetal entanglements, true knots (sometimes multiple) and they are prone for torsion. Grading system of tight nuchal cords as ${ }^{7}$

- Grade 1: Conjunctival hemorrhage and petechiae.

- Grade 2: Duskiness of face, facial suffusion and pallor.

- Grade 3: Respiratory distress, stupor and hypotonia requiring resuscitation. ${ }^{8}$

The aims and objectives are to find out incidence of nuchal cord at delivery, to compare and evaluate course of labour and mode of delivery in both groups, to compare and evaluate intrapartum complication and fetomaternal outcome in patients with or without nuchal cord at delivery

\section{METHOD}

A prospective cross-sectional comparative study was done at tertiary care hospital for period of 12 months. Total 1380 deliveries occurred in this period and patients were enrolled for the study as per the inclusion and exclusion criteria.

\section{Inclusion criteria}

- Singleton gestation (>28 weeks) with umbilical cord forming loop around neck of the baby at the time of delivery.

\section{Exclusion criteria}

- Multiple gestations, previous LSCS,

- PIH,

- Oligohydramnios,

- Polyhydramnios,

- Postdatism,

- Patients undergoing Elective LSCS (lower segment caesarean section),

- IUFD's (intra-uterine fetal death).

After inclusion and exclusion criteria were met, patients enrolled in the study as per occurrence were divided into two groups,

- Study group: Delivery with nuchal cord

- Control group: Delivery without nuchal cord

Selection of patients: Out of the total 1380 deliveries, 934 patients were enrolled in present study based on above inclusion criteria and 446 patients were excluded based on the exclusion criteria. Out of these 934 patients, 150 patients delivered with nuchal cord around neck and 784 patients delivered without nuchal cord around neck.

Following outcomes were measured between both groups: duration of active labour, duration of second stage, meconium staining of liquor, fetal distress, number of instrumental deliveries, number of LSCS, APGAR score $<7$ at 1 st $\mathrm{min}$ and 5 th $\mathrm{min}$, admission to NICU. Above data was entered in proforma and analysed by SPSS version.

\section{RESULTS}

Out of 1380 delivered patients after 28wks, 260 patients had nuchal cord making its incidence $18.84 \%$ of which 150 patients had nuchal cord after following exclusion criteria. Of these 150 patients, $138(92 \%)$ patients had 1 loop of cord, $10(6.7 \%)$ patients had 2 loops of cord and $2(1.3 \%)$ patient had 3 loops of cord (Table 1$)$.

Table 1: Incidence of nuchal cord at delivery and number of loops at the time of delivery.

\begin{tabular}{|l|l|l|}
\hline No. of loops & Frequency & $\%$ \\
\hline 1 loop & 138 & 92 \\
\hline 2 loops & 10 & 6.7 \\
\hline 3 loops & 2 & 1.3 \\
\hline Total & 150 & 100 \\
\hline
\end{tabular}

Mean duration of active phase was $6.51 \mathrm{hrs}$ in study group and 6.15 hours in control group and the difference was statistically significant.

Mean duration of second stage of labour was $0.46 \mathrm{hrs}$ in study group and $0.45 \mathrm{hrs}$ in control group and the difference was statistically not significant (Table 2).

Table 2: Comparison of duration of labour between both groups.

\begin{tabular}{|l|l|l|l|}
\hline Intrapartum & $\begin{array}{l}\text { With } \\
\text { nuchal } \\
\text { cord }\end{array}$ & $\begin{array}{l}\text { Without } \\
\text { nuchal } \\
\text { cord }\end{array}$ & Statistics \\
\hline $\begin{array}{l}\text { Mean duration } \\
\text { of active labour } \\
\text { (hours) }\end{array}$ & 6.51 & 6.15 & $\begin{array}{l}\text { P value=0.024 } \\
\text { (significant) }\end{array}$ \\
\hline $\begin{array}{l}\text { Mean duration } \\
\text { of second stage } \\
\text { (hours) }\end{array}$ & 0.46 & 0.45 & $\begin{array}{l}\text { P value=0.894 } \\
\text { (not significant) }\end{array}$ \\
\hline
\end{tabular}

In study group of 150 patients, only $14(9.33 \%)$ patients had meconium stained liquor as compared to $68(8.67 \%)$ patients in control group whereas $12(8 \%)$ patients had fetal distress in study group as compared to $62(7.90 \%)$ patients in control group and the difference was statistically not significant (Table 3).

Out of 150 patients in study group, 114(76\%) patients had normal delivery, $10(6.66 \%)$ patients had instrumental delivery and $26(17.33 \%)$ patients had LSCS. 
Table 3: Comparison of meconium staining of liquor and fetal distress between the two groups.

\begin{tabular}{|c|c|c|c|c|c|}
\hline \multirow[t]{2}{*}{ Intrapartum } & \multicolumn{2}{|c|}{$\begin{array}{l}\text { With } \\
\text { nuchal } \\
\text { cord } \\
(n=150)\end{array}$} & \multicolumn{2}{|c|}{$\begin{array}{l}\text { Without } \\
\text { nuchal } \\
\text { cord } \\
(\mathrm{n}=784)\end{array}$} & \multirow[t]{2}{*}{ Statistics } \\
\hline & No. & $\%$ & No. & $\%$ & \\
\hline $\begin{array}{l}\text { Meconium } \\
\text { stained } \\
\text { liquor }\end{array}$ & 14 & 9.33 & 68 & 8.67 & $\begin{array}{l}\mathrm{P} \text { value- } \\
0.853 \text { (not } \\
\text { significant) }\end{array}$ \\
\hline Fetal distress & 12 & 8 & 62 & 7.90 & $\begin{array}{l}\mathrm{P} \text { value- } \\
0.978 \text { (not } \\
\text { significant) }\end{array}$ \\
\hline
\end{tabular}

Out of 784 patients in control group, 612(78.06\%) patients had normal delivery, 30(3.82\%) had instrumental delivery and $142(18.11 \%)$ patients had LSCS and the difference was statistically not significant (Table 4).

Table 4: Comparison of mode of delivery between patients with and without nuchal cord.

\begin{tabular}{|c|c|c|c|c|c|}
\hline \multirow[t]{2}{*}{$\begin{array}{l}\text { Mode of } \\
\text { delivery }\end{array}$} & \multicolumn{2}{|c|}{$\begin{array}{l}\text { With nuchal } \\
\text { cord }(n=150)\end{array}$} & \multicolumn{2}{|c|}{$\begin{array}{l}\text { Without } \\
\text { nuchal cord } \\
(n=784)\end{array}$} & \multirow[t]{2}{*}{ Statistics } \\
\hline & No. & $\%$ & No. & $\%$ & \\
\hline Normal & 114 & 76 & 612 & 78.06 & \multirow{3}{*}{$\begin{array}{l}\text { P value- } \\
0.538 \text { (not } \\
\text { significant) }\end{array}$} \\
\hline Instrumental & 10 & 6.66 & 30 & 3.82 & \\
\hline LSCS & 26 & 17.33 & 142 & 18.11 & \\
\hline
\end{tabular}

Mean length of nuchal cord of the patients delivering with nuchal cord around the neck is $45.39 \mathrm{~cm}$ as compared to $44.64 \mathrm{cms}$ in the patients delivering without nuchal cord which is statistically significant (Table 5).

Table 5: Comparison of length of cord after delivery between the two groups.

\begin{tabular}{|c|c|c|c|}
\hline & $\begin{array}{l}\text { With } \\
\text { nuchal cord }\end{array}$ & $\begin{array}{l}\text { Without } \\
\text { nuchal cord }\end{array}$ & Statistics \\
\hline $\begin{array}{l}\text { Mean length } \\
\text { of cord }(\mathrm{cm})\end{array}$ & 45.39 & 44.64 & $\begin{array}{l}\text { P value- } \\
0.01 \\
\text { (significant) }\end{array}$ \\
\hline
\end{tabular}

Out of patients with APGAR $<7$ at $1 \mathrm{~min}, 14(9.33 \%)$ patients were from study group and $66(8.41 \%)$ patients were from control group and the difference was statistically not significant.

Out of patients with APGAR $<7$ at 5 mins, 14(9.33\%) patients were from study group and $66(8.41 \%)$ patients were from control group and the difference was statistically not significant.

Out of patients with NICU admissions, 10(6.66\%) patients were from study group and $48(6.12 \%)$ patients were from control group and the difference was statistically not significant (Table 6).
Table 6: Neonatal outcome.

\begin{tabular}{|c|c|c|c|c|c|}
\hline \multirow[t]{2}{*}{$\begin{array}{l}\text { Neonatal } \\
\text { outcome }\end{array}$} & \multicolumn{2}{|c|}{$\begin{array}{l}\text { With } \\
\text { nuchal } \\
\text { cord } \\
(\mathrm{n}=150)\end{array}$} & \multicolumn{2}{|c|}{$\begin{array}{l}\text { Without } \\
\text { nuchal } \\
\text { cord }(n=784)\end{array}$} & \\
\hline & No. & $\%$ & No. & $\%$ & \\
\hline $\begin{array}{l}\text { Apgar }<7 \\
\text { at } 1 \mathrm{~min}\end{array}$ & 14 & 9.33 & 66 & 8.41 & $\begin{array}{l}\mathrm{P} \text { value- } \\
0.795 \text { (not } \\
\text { significant) }\end{array}$ \\
\hline $\begin{array}{l}\text { Apgar }<7 \\
\text { at } 5 \text { mins }\end{array}$ & 14 & 9.33 & 66 & 8.41 & $\begin{array}{l}\text { P value- } \\
0.795 \text { (not } \\
\text { significant) }\end{array}$ \\
\hline $\begin{array}{l}\text { NICU } \\
\text { admission }\end{array}$ & 10 & 6.66 & 48 & 6.12 & $\begin{array}{l}\text { P value- } \\
0.796 \text { (not } \\
\text { significant) }\end{array}$ \\
\hline
\end{tabular}

\section{DISCUSSION}

The incidence of nuchal cord in this study was $18.84 \%$ of all the deliveries after 28 weeks of gestation which is similar to the study done by Peregrine et al which showed $18 \%$ incidence of nuchal cord. ${ }^{9}$ Larson JD et al.10 reported that the overall incidence of nuchal cords was $6 \%$ at 20 weeks GA and $29 \%$ at 42 weeks of gestation. It was also found that $2.4 \%$ to $8.3 \%$ of all pregnancies had equal to or more than 2 loops of cord around neck. Henry, et al observed incidence of tight nuchal cord around neck was $6.6 \%$ and $21.6 \%$ had loose nuchal cord. ${ }^{11}$ The incidence of one coil of the umbilical cord around the neck was 61(17.43\%), while two coils and three coils of the cord occurred in five $(1.43 \%)$ and two $(0.57 \%)$ of the deliveries, respectively which was similar to present study. ${ }^{12}$ Difference in duration of active labour in both groups was statistically significant.

Difference in duration of second stage of labour was statistically not significant. However, studies could not be found comparing duration of phases of labour in each group. Difference in meconium stained liquor and fetal distress were statistically not significant which is comparable with study conducted by Spellacy et al and Mastrobattista et al. Instrumental delivery rate was slightly more in study group than control group but statistically not significant. ${ }^{13,14}$ This finding is similar to study conducted by of Peregrine et al, Schaffer et al, Mastrobattista et al., ${ }^{8,15}$ There was no statistically significant difference in the number of operative deliveries or in Apgar scores at 1 and 5 minutes between these two groups which is comparable with study conducted by Miser WF3 and G Singh. ${ }^{12}$ NICU admission rate in both groups was also statistically not significant and comparable to study done by Gonzalez et al and G Singh. ${ }^{12,16}$

\section{CONCLUSION}

Loop of umbilical cord around fetal neck occurs commonly and is associated with prolonged active phase but it is rarely associated with maternal and neonatal 
morbidity or mortality. Hence, the decision of doing Caesarean section in these cases only increase maternal morbidity and mortality without altering perinatal outcome. So, the ultrasound diagnosis of a nuchal cord at term should per se not be the indication of elective cesarean delivery and with watchful monitoring patient can be delivered vaginally.

Funding: No funding sources

Conflict of interest: None declared

Ethical approval: The study was approved by the Institutional Ethics Committee

\section{REFERENCES}

1. Crawford JS. Cord around the neck. Acta Paediatrica. 1962;51(5):594-603.

2. Clapp JF, Stepanchak W, Hashimoto K, Ehrenberg $\mathrm{H}$, Lopez B. The natural history of antenatal nuchal cords. Am J Obstet Gynecol. 2003;189(2):488-93.

3. Miser WF. Outcome of infants born with nuchal cords. J Fam Pract. 1992;34(4):441-5.

4. Jauniaux E, Ramsay B, Peellaerts C, Scholler Y. Perinatal features of pregnancies complicated by nuchal cord. Am J Perinatol. 1995;12(4):255-8.

5. Ranzini AC, Walters CA, Vintzileos AM. Ultrasound diagnosis of nuchal cord: the gray-scale divot sign. Obstet Gynecol. 1999;93(5):854.

6. Krakowiak P, Smith EN, de Bruyn G, LydonRochelle MT. Risk factors and outcomes associated with a short umbilical cord. Obstet Gynecol. 2004;103(1):119-27.

7. Naeye RL. Umbilical cord length: clinical significance. J Pediatr. 1985;107(2):278-81.

8. Stapczynski JS, Dietrich AM. Theories of strangulation injuries. Emergency Medicine Reports, A Pract J Emerg Phy. 2010;3117):195-6.

9. Peregrine E, O'Brien P, Jauniaux E. Ultrasound detection of nuchal cord prior to labour induction and the risk of caesarean section. Ultrasound Obstet Gynecol. 2005;25(2):160-4.

10. Larson JD, Rayburn WF, Crosby S, Thurnau GR. Multiple nuchal cord entanglements and intrapartum complications. Am J Obstet Gynecol. 1995;173(4):1228.

11. Henry E, Andres RL, Christensen RD. Neonatal outcomes following a tight nuchal cord. J Perinatol. 2013;33(3):231.

12. Col GS, Maj KS Nuchal Cord: a retrospective analysis: Med J Armed Forces India. 2008;64(3):237-40

13. Spellacy WN, Gravem H, Fisch RO. The umbilical cord complications of true knots, nuchal coils, and cords around the body. Am J Obstet Gynecol 1966;94(8):1136-42.

14. Mastrobattista JM, Hollier LM, Yeomons ER, Ramin SM. Day MC, Sosa A et al 3rd. Effects of nuchal cord on birthweight and immediate neonatal outcomes. Am J Perinatol. 2005;22(2):83-5.

15. Leonard Schaffer, Tilo Burkhardt, Ronald Zimmermann and Juozas Kurmanavicious. Nuchal Cords in Tern and Post term deliveries- Do we need to know? Obstetrics and Gynecology. 2005;106(1):23-8.

16. González-Quintero VH, Tolaymat L, Muller AC, Izquierdo L, O'Sullivan MJ, Martin D. Outcomes of pregnancies with sonographically detected nuchal cords remote from delivery. J Ultrasound Med. 2004;23(1):43-7.

Cite this article as: Sonawane $\mathrm{PK}$, Bhadra DM.

Comparative study of maternal and perinatal outcome in pregnancies with and without umbilical cord around foetal neck. Int J Reprod Contracept Obstet Gynecol 2019;8:1096-9. 